\title{
Innovative approaches to nisin production
}

\section{Özel, B}

2018-08

Özel , B , Simsek , Ö , Akcelik, M \& Saris , P E J 2018 , ' Innovative approaches to nisin production ' , Applied Microbiology and Biotechnology , vol. 102 , no. 15 , pp. 6299-6307 . https://doi.org/10.1007/s0

http://hdl.handle.net/10138/309914

https://doi.org/10.1007/s00253-018-9098-y

unspecified

acceptedVersion

Downloaded from Helda, University of Helsinki institutional repository.

This is an electronic reprint of the original article.

This reprint may differ from the original in pagination and typographic detail.

Please cite the original version. 
2 Burcu Özel ${ }^{1}$, Ömer Şimşek ${ }^{2}$, Mustafa Akçelik $^{3}$, Per E. J. Saris ${ }^{4}$

3 1: University of Pamukkale, Çal Vocational High School, Department of Food Processing,

4 Denizli, Turkey

5 2: University of Pamukkale, Department of Food Engineering, Denizli, Turkey

$6 \quad$ 3. University of Ankara, Department of Biology, Ankara, Turkey

$7 \quad$ 4: University of Helsinki, Department of Microbiology, Helsinki, Finland

8

9

10

11

Corresponding Author:

Ömer Şimşek, PhD

University of Pamukkale, Department of Food Engineering

Denizli, Turkey, 20017

Tel: +90 2582963015

Fax: +902582963262

Email: omers@pau.edu.tr 


\section{Abstract}

Nisin is a bacteriocin which is produced by Lactococcus lactis and approved by FDA to be utilized as GRAS status food additive. Nisin has antimicrobial activity against Listeria, Clostridium, Staphylococcus and Bacillus species or spores. Also it some circumtances, it has an immune modulator role and a selective cytotoxic effect against cancer cells. However, it is notable that the high production cost of nisin is an important issue which restricts its intensively use. The major reason is the low nisin production yield of producer strains. In recent years, the production of nisin has been significantly improved by genetic modifications in nisin producer strains or also innovative applications in fermentation conditions. Recently, $15400 \mathrm{IU} / \mathrm{mL}$ nisin production has been achieved in L. lactis cells by genetic modifications with eliminating the factors that affect nisin biosynthesis or by increasing the density of the producing strains in the fermentation medium. In this review, the innovative approaches, which were applied in cell and fermentation systems where nisin production is increased, are comparatively discussed and interpreted regarding developing industrial nisin production.

Keywords: Nisin, innovative system, fermentation, bacteriocin

\section{Introduction}

Nisin is a bacteriocin of the type I lantibiotic group, which is produced by Lactococcus lactis (Hurst, 1981). This bacteriocin has a wide antimicrobial activity against the spores of Grampositive bacteria, as well as especially the food pathogens Listeria monocytogenes, Staphylococcus aureus, Clostridium and Bacillus species. Nisin can show an inhibition effect on Gram-negative pathogen species (such as Escherichia coli and Salmonella) when used together with applications that disrupt the cell wall such as EDTA, thermal treatment and freezing (Belfiore et al. 2007). Nisin is a cationic, hydrophobic, heat-resistant peptide with a 
molecular weight of $3500 \mathrm{Da}$. In the structure of this molecule, there are the dehydroalanine (DHA), dehydrobutyrine (DHB), lanthionine and $\beta$-methylantionine amino acids that are scarce in nature and that are connected to each other by thioether bridges. To date, five variants have been characterized as follows: nisin A (Gross and Morell 1971), nisin Z (Graeffe et al. 1991; Mulders et al. 1991), nisin Q (Zendo et al. 2003), nisin U (Wirawan et al. 2006) and nisin F (Kwaadsteniet et al. 2008). Nisin A, Z and U producers have been isolated from milk and dairy products (Gross and Morell 1971, Graeffe et al. 1991; Mulders et al. 1991), nisin Q producer from river water (Zendo et al. 2003) and nisin F producer from catfish (Kwaadsteniet et al. 2008). Of these variants, only nisin U is produced by a bacteria (Streptococcus uberis) other than the L. lactis strains.

Nisin, as it has a wide antimicrobial spectrum and as it is decomposed by the digestive enzymes, has been defined and documented (E234) by the FDA (Food and Drug Administration) as a GRAS agent (Generally Recognized As Safe) and has been allowed to be used in food systems (Luck, 1995). Nisin was used in the 1950s to solve the problem arose from Clostridium tyrobutyricum in cheese. Currently, commercial nisin preparations are being produced in powder form of 2,5\% purity and having $40 \times 10^{6} \mathrm{IU}$ (International Unite) biological activity in one gram (Tramer and Fowler, 1964). Today, nisin is used in the production of various cheese, ready-made soups and canned foods.

The current industrial nisin production is carried out in batch fermentation systems by growing the nisin A producing L. lactis cells in supplemented whey or milk medium, and the product is subsequently partially purified. However, the high cost of industrial nisin production is an important issue that restricts widespread use of this bacteriocin in food systems due to the low production yield of the producer cells, the feedback inhibition factors depending on fermentation conditions and the sensitivity of the producers to nisin. Therefore many studies 
have focused on the elimination of the factors that restrict the amount of production since the high commercial value of nisin. These studies have demonstrated that high amount of nisin production is closely related with the biomass amount as well as the genetic properties of the producer cells, the fermentation conditions and the fermentation metabolites which cause feedback inhibitions. In this respect, many innovative systems have been developed by the researchers to eliminate these restrictions such as, metabolic regulation at producers aiming the increase biomass and relatively nisin, high producer construct which could overcome the restrictions and fermentation optimization in term of $\mathrm{pH}$, temperature, substrate and dissolved oxygen concentrations (Kong and Lu, 2014; Simsek, 2014; Zhu et al. 2015; Papagianni ve Avramidis, 2012; Hao et al. 2017; Ni et al. 2017; Liu et al. 2017; Zhang et al. 2014; Zhang et al. 2016; Kordikanlioglu et al. 2015; Zheng et al. 2015; Jiang et al. 2015; Ariana ve Hamedi, 2017).

In this review, the innovative approaches applied in cell and fermentation systems where nisin production was increased, were comparatively discussed and were interpreted concerning development of industrial nisin production. Firstly, the current commercial nisin production was evaluated, then the studies aiming for increasing the nisin production in cells and the applications in fermentation conditions were subsequently disscussed. Thus, a perspective to improve industrial nisin production was tried to be established in this paper.

\section{Commerical Production of Nisin}

Commercial nisin has been produced in batch fermentation systems at industrial scale. Whole milk or skim milk is sterilized after the casein or para-casein fractions separated by enzymatically or acidification and subsequently the whey is used as a substrate to grow the producer L. lactis in large scale reactor systems. The fermentation conditions were kept under 
promoting conditions whereas the $\mathrm{pH}$ is 6.0 and temperature is $30^{\circ} \mathrm{C}$. In the optimum production conditions, nisin producer L. lactis cells show common bacterial growth curve where the highest nisin activity is measured after $8 \mathrm{~h}$ and reached maximum at $12 \mathrm{~h}$ of fermentation. However, suprisingly nisin activity dramatically decreased at the following hours of fermentation. Figure 1 shows the repsentative cell growth and relavant nisin production versus to time scale. After fermentation, the foaming procedure is applied to the fermentate to separate and partially to concentrate the produced nisin. Firstly, the fermentate $\mathrm{pH}$ is reduced to 4.50 that enables the precipitation of milk protein such as casein and serum proteins. Then, the fluid is taken into the system which contains circulating vertical tubes. To ensure that the nisincontaining liquid is foamed, $0.1 \%$ Tween is added; ventilating from the bottom, the foam formed at the top is collected. At the last stage, sodium chloride and acetone are used to separate nisin and the precipitate is dried. Thus, commercial nisin preparation that has a purity of $2.5 \%$ and an activity of 40x $10^{6} \mathrm{IU}$ in 1 gram is obtained (Patent, US2935503 A).

The main aim at nisin production is to increase the amount of active producing cells in fermentation to achieve high nisin production yield. On the other hand, at nisin production, the lactic acid produced by the L. lactis resulted feedback inhibition on the producer cells. Accumulation of the lactate concentration in the medium accelerates protein denaturation in the cells, it also causes the L. lactis cells to spend more energy to be able to tolerate the unfavourable fermentation condition. These adversities lead to the disruption of active nisin production phase in the L. lactis cells and even to a decrease in cell density. Another factor that inhibits nisin production is a high concentration of nisin produced in the fermentation. The high amount of nisin that is produced by L. lactis cells in turns inhbited the itself, although these producer cells have a limiting or resistance level against nisin concentration (Kim et al. 1998; Ra et al. 1996; Kim et al. 1998). 
The innovative studies, such as constructing producer strains giving high yield through genetic manipulations in the producing cells to minimizing the factors affecting nisin production and re-routing the metabolic pathways in producing cells or ensuring special fermentation conditions are the main targets of the studies which aim increasing the nisin production. The innovative approaches applied have provided higher nisin production at various levels. In Table 1 recently high nisin production innovative sytems are listed.

\subsection{Recombinant Nisin Producers}

Characterization the molecular mechanism of nisin biosynthesis and metabolic regulation on species level have opened the way to genetic regulation efforts to increase the yield in nisin production. Within this context, the genetic manipulations have focused on the problems that restrict nisin production, including i) the high nisin concentration in the medium, ii) high lactate accumulation and iii) low biomass formation.

The active nisin production is coded by the $14 \mathrm{~kb}$ site of the conjugative nisin-saccharose transposon that carries 11 genes (nisA/Z/Q BTCIPRKFEG). This gene cluster includes two operons (nisA/Z/Q BTCIPRK and nisFEG) and is transcribed as three different mRNA molecules (nisA/Z/Q, nisBTCIPRK and nisFEG). Of the genes in this site, nisA/Z/Q encodes for the synthesis of the pre-peptide; nisB, $C$ encodes for the modification of the pre-peptide after translation; $n i s P$ encodes for the protease that allows the formation of the nisin peptide from pre-nisin; nis $T$ encodes for the transfer of the prenisin molecule; nisF,E, $G$ encodes for the resistance of the producing cell to nisin; nisR, $K$ encodes for the transcriptional regulation of nisin production. The regulation of nisin production is ensured by a dual regulation system comprising histidine kinase (NisK) and its regulator (NisR) and nisin, in turn, induces the 
transcription of the biosynthesis genes (Engelke et al., 1992; Kuipers et at., 1995; Ra et al., 1996).

Increasing the copy number of the key genes in nisin biosynthesis directly contributed to the increase of nisin production. Likewise, in the studies, increasing the copy number of the regulation and resistance genes (nisRK, nisFEG) involved in nisin biosynthesis in producing cells significantly improved nisin production (Kim et al., 1998; Cheigh et al. 2002; Simsek et al., 2009a,b; Ni et al. 2017). Although nisin is functional in its own biosynthesis as a regulator, nisin producing L. lactis cells are adeversely affected by nisin. Particularly in the later times of fermentation, high nisin accumulation in the growing medium causes disruption on the cell membranes of the producer L. lactis strains. Although various proteins have been produced in L. lactis cells against the nisin are produced, the producers have different level of resistance against nisin. Thus, increasing the expression of nisin resistance genes (nisI, nisF,nisE and $n i s G$ ) in producer L. lactis cells enhanced the resistance against nisin. Because, as elucidated, there is a nisin tolerance limit at each producer cells. A relevant study reported that by transferring nisI genes on a vector plasmid to the wild type producer strain and ensuring the expression of these genes resulted $20 \%$ increase in the amount of nisin production (Kim et al. 1998). Using the nisI gene led the way to increase the copy number of the other genes in the operon at the producer cells. In a study conducted on this basis, it was attempted to increase nisin $\mathrm{Z}$ production in an L. lactis subsp. lactis 164 strain by cloning the essential gene (nisZ), regulations genes (nisR, nisK) and the resistance genes (nis $F, n i s E, n i s G)$. Nisin activity which was $16,000 \mathrm{AU} \mathrm{ml}^{-1}$ in the control strain was improved to $25,000 \mathrm{AU} \mathrm{m}{ }^{-1}$ by increasing the copy number of the regulatory genes. The transcription of the nis $Z$ gene when the nisR and nisK genes were highly expressed and resulted favorable improvements (Cheigh et al. 2002). In another study, the copy number of the nisin regulation and resistance genes (nisRKFEG) in the L. lactis LL27 strain was increased simultaneously which gained $45 \%$ increase in nisin 
production compared to that of the wild type strain. In the same study, in the batch fermentation system of the recombinant strain, in which the copy number of the nisRKFEG genes were simultaneously increased, the dramatic losses experienced in the nisin activity of the control strain in the late hours of the fermentation was prevented (Simsek et al. 2009a). In nisin production in continuous nisin fermentation, increasing the copy number of the regulation and resistance genes simultaneously has allowed working at high dilution ratios $\left(0.29 \mathrm{~h}^{-1}\right)$ of the producer strain. Thus, a significant increase was ensured in specific nisin production amount (Simsek et al. 2009b).

In industrial nisin production, the $\mathrm{pH}$ that decreases due to the production of lactic acid by $L$. lactis is neutralized by adding alkali to establish suitable physiological conditions for the cells in question. However, the lactate that accumulates in the medium at progressive hours of the fermentation inhibits cell proliferation, and consequently, there are losses in nisin production. Examining the nisin production graphs in batch systems, it is seen that nisin activity seriously decreases towards the end of the fermentation. It is discussed that in such a case, the cells undergo autolysis and release proteases and thus the nisin activity decreases. One of the first steps taken to solve this identified problem is cloning and expressing the pyruvate decarboxylase (PDC) and alcohol dehydrogenase (ADH) genes to direct the carbohydrate metabolism in L. lactis cells to ethanol production. As Wardani et al. (2006) pointed out nisin production in the cells in which the metabolic pathway is converted to heterofermentative has increased 1.7 times.

One of the objectives of increasing nisin production is improving the tolerance of the cells to acidic conditions in the fermentation medium. In a study within this context, it was ensured that the asparagine synthetase $(a s n \mathrm{H})$ gene was expressed more to increase the ratio of D-Asp amidation in the cell wall composition of the L. lactis F44 strain. The tolerance of the 
recombinant L. lactis F44A strain obtained was improved at a significant level, and consequently, it was determined that the F44A strain could produce more nisin in the fermentation media compared to the wild type strain. In both batch and fed-batch fermentation systems, 2884 and $3405 \mathrm{IU} \mathrm{ml}^{-1}$ nisin were produced at wild type $\mathrm{F} 44$ strain where as the nisin production was enhanced to 3876 and $5346 \mathrm{IU} \mathrm{ml}^{-1}$ nisin was achieved respectively at the acidtolerant L. lactis F44A strain respectively (Hao et al. 2017). In another study with the paralel hypothesis, 17 genes giving acidic tolerance were transferred to L. lacits F44 sustaining the optimum $\mathrm{pH}$ value in the cell, Among these genes, the $h d e A B, I d h$ and $m u r G$ resulted the highest amount of nisin production at recombinant L. lactis cells (5560 $\mathrm{IU} \mathrm{ml}^{-1}$ ) (Zhang et al. 2016). These results are also the evidences showing the adverse effect of the lactate on nisin production.

The nisin production amount is closely dependent on the biomass yielded in the fermentation. Hence, the presence of active producer cells in the system promoted nisin production. Therefore, many studies aimed to increase the physiological wellness or the number of the active nisin-producing cells under fermentation conditions. Especially, increasing the energetic level of the producers is one of the most basic approach. For example, Papagianni and Avramidis (2012) provided the cells to be produced more energy with some manipulations promoting the oxidative respiration in the nisin producer, thus accelerating cell division and metabolism under fermentation conditions. In this study, Papagianni and Avramidis succeded to clone the aoxl gene from Aspergillus niger to the nisin producer L. lactis ATCC11454 and used it in a fermentation system consisted $90 \%$ dissolved oxygen and $10 \mathrm{~g} \mathrm{l}^{-1}$ glucose concentration. Accordingly, the biomass and nisin production of L. lactis ATCC11454 was 3.2 $\mathrm{g}^{-1}$ and $5900 \mathrm{IU} \mathrm{ml}^{-1}$ while the aoxl gene including L. lactis ATCC11454 produced $5.8 \mathrm{~g} \mathrm{l}^{-1}$ and $7900 \mathrm{IU} \mathrm{ml}^{-1}$ biomass and nisin respectively. This enhancement revealed the necessity to express the $p f k$ gene encoding the phosphofructokinase (pfk) together with the aoxl gene in $L$. 
lactis ATCC11454. Thereby, the aoxl gene was further cloned to the L. lactis ATCC11454 together with the $p f k 13$ ve $p k a C$ genes responsible for the phosphofructokinase and AMP protein kinase and it was demonstrated that the biomass and nisin production of the recombinants including the pfk13-pkaC-aoxl genes in a fed-batch fermentation system containing hemin reached $7.5 \mathrm{~g} \mathrm{~L}^{-1}$ and $14000 \mathrm{IU} \mathrm{mL}^{-1}$ the highest nisin activity ever reported (Papagianni and Avramidis, 2012). In another similar study, the 8-phosphofructokinase $p f k$ gene was expressed in the L. lactis N8 strain and 20\% more nisin yield was obtained in the recombinant strain after 10 hours of fermentation (Zhu et al. 2015).

Well organized and optimized fermentation systems enable to produce high amount of nisin. Thus increase at nisin production and yield was been hypothesized for continuous fermentation if the nisin producer L. lactis cells could be kept in reactor against dilution. In this respect, the gene encoding the chitin binding domain of chitinase, one of the enzyme cleaving the chitin which is the abundant polysaccharide in nature, was successfuly cloned and expressed in nisin producer L. lactis N8. Subsequently, the chitin which the cells be intact was used in the continuous fermentation system of the study to prevent the cell outflow. In the system, the nisin producers that can adhere to chitin, remain in the continuous fermentation system (CICONFER), and a nisin production over $10000 \mathrm{IU} \mathrm{mL}^{-1}$ was able to be produced with $0.9 \mathrm{~h}^{-1}$ dilution rate (Simsek, 2014).

In the another innovative study, to increase nisin $\mathrm{Z}$ production in the L. lactis YF11 strain, genome shuffling was applied using repeated protoplast fusion method. In genome shuffling, ultraviolet radiation and diethyl sulfate mutagenesis were used for template line production. After 4 rounds of shuffling, an F44 strain that can tolerate both high glucose ( $8 \%$ to $15 \% \mathrm{w} / \mathrm{v})$ and high nisin concentrations (5000-14000 IU ml-1) was obtained. This recombinant nisin producer produced 2.4 fold more $\left(4023 \mathrm{IU} \mathrm{ml}^{-1}\right)$ nisin in the fed-batch fermentation system 
comparing to the YF11 control strain. The findings showed that the transcription levels of nisZ and nisI, the structural genes of nisin, in the F44 were higher ( $48 \%$ and $130 \%$ respectively) compared to those of the control strain (Zhang et al. 2014).

\subsection{Modified Nisin Fermentation Systems}

Nisin production was first carried out in batch systems, then, fed-batch fermentation systems were used. Relevant studies have demonstrated that the factors limiting nisin production are: i) inhibition of producers by high substrate concentration, ii) lactate repression on producers, iii) nisin feedback inhibition on producers, and iv) nisin degradation by the proteases released from the cells. To eliminate these disadvantages, various innovative modifications have been made in fermentation systems which have contributed to some extend to the improvement of nisin production (e.g., de Vuyst 1992; Pongtharangkul et al. 2006; Simsek et al. 2009).

One of the fermentation trials carried out for nisin production was cycling the active nisin producer cells that cultivated in the batch system into the fresh substrate. This application sustained the active physiological state of the logarithmic phase cells in the batch system maintaining the high nisin production characteristics. Bertrand et al. (2001) transferred $10^{11}$ CFU g ${ }^{-1}$ L. lactis subsp. lactis biovar. diacetylactis cells, immobilized on k-carrageenan/legume gum onto a fresh medium every one hour and achieved $8200 \mathrm{IU} \mathrm{ml}^{-1}$ total nisin activity and $5730 \mathrm{IU} \mathrm{ml} \mathrm{H}^{-1} \mathrm{~h}^{-1}$ volumetric nisin activity. However, since the cells were stabilized in solid phase, the substrate access and also the high nisin concentration exposed to cells were the adverse factors. In another similar study, to increase the specific nisin production, L. lactis N8 and LAC48 strains were grown in the batch system and every 30, 60 and 120 min cells were seperated and suspended in the fresh substrate. Thus, nisin production was sustained with continuously in active phase. Although high nisin productivity was attained in 60 min cycles, 
the cellular stability could be maintained more in 30 min cycles. However the cell stability decreased within $120 \mathrm{~min}$ at nisin producers significantly after $5^{\text {th }}$ cycle. In this study, $60 \mathrm{~min}$ cycle was offered continuously produce nisin with high productivity (Şimşek et al. 2009).

The high substrate concentrations in the fermentation medium adversely affect the nisin producers. Therefore, fed-batch fermentation systems are recommended in nisin production instead of batch fermentation systems. However, some studies to prevent the high substrate inhibition in fed-batch fermentation systems are still carried out. Malvido et al. (2016), realkalized the medium in line according to the $\mathrm{pH}$ reduction rate of the cells in the fermentor and glucose was added depending on the amount of spent $\mathrm{NaOH}$. In this fermentation system, glucose was used by monitoring the activity of the L. lactis CECT539 cells. As a result, it was reported that use of $400 \mathrm{~g} \mathrm{~L}^{-1}$ glucose in fed-batch fermentation system, where the medium was re-alkalined increased the production and this system was established an alternative for economic nisin production.

Nisin production is closely associated with the number and the physiological stability of the producing cells in the fermentor medium. It is notable that particularly a high number of active producing cells in the fermentor significantly increase the nisin production. It is known that bacterial activity is related with the energetic level. Therefore, nisin producer L. lactis cells were promoted to oxidative respiration in fermentor systems inducing heterofermentative instead of homofermentative metabolism which resulted the cells have high energy by activating the ETS system. Figure 2 is showing heterofermentative metabolism of a L. lactis when the aerobic fermentation is applied in the presence of hemin. Additionally, this reroute of metabolism also resulted higher biomass after fermentation. Because acetone, diacetyl and ethanol were produced instead of lactic acid which avoided lactate acumulation. Thereby lactate inhibition could be also eliminated by heterofermentative metabolism. 
Respiration of facultative anaerobic L.lactis cells is only possible by the activation of cytochromes in the fermentation media where hemin and hemin-menachinon are present (Bryan-jones et al. 1969; Sijpestejn 1970; Whittenbury et al. 1978; Lechardeur et al. 2004; Brooijmans et al. 2009; Pedersen et al. 2012). However, since lactic acid bacteria do not have the enzymes to carry out hemin biosynthesis, adding hemin into the medium is necessary to start respiration in these strains.

There is only one type of cytochrome oxidase (CydAB) enzyme in all lactic acid bacteria. This enzyme complex can function in media containing oxygen and contributes to the oxygen tolerance of the bacterial cell (Rezaiki et al. 2004). The cytochromes inducing the proton motive force by being final proton acceptor in membranes warrant the cell to be able to respire in media even with low oxygen concentration (Brooijmans et al. 2009). L. lactis that is known for its fermentative metabolism can respire under aerobic conditions in the presence of hemin since it has the $c y d \mathrm{AB}$ gene. Bolotin et al. (1999) reported that the $c y d A$ gene is present in the genome of the L. lactis IL1403 strain responsible for the respiration encoded by cytochrome bd oxidase. During respiration, the $c y d A$ gene play an active role in the electron transfer system and enable ATP production with transferring the electrons to the oxygen.

In the fed-batch fermentation system, where the glucose, hemin and dissolved oxygen concentrations were optimized and the L. lactis N8 induced for respiration was used, nisin production was 3.1 times more than the control group fermented without hemin and a maximum nisin production of $5410 \mathrm{IU} \mathrm{ml}^{-1}$ was achieved. It was reported that this increase in nisin production was attributed to the increase in cell biomass within the energetic level in the producing strain and to the minimizing the feedback inhibition by the lactate accumulated in the medium (Kordikanlioglu et al. 2015). 
Nisin also has antimicrobial activity on itself. Although there are immunity proteins and various proteases in the cell wall to protect from nisin, the high concentration accumulated in the fermentation seriously affect the producer strains. Therefore, one of the issues on which researchers focus on is to online separation of nisin from the fermentation system. Indeed, this success will also allow the nisin to be concentrated and pure. The foam fractionation method is an innovative method for obtaining nisin and similar surfactant compounds from media at low cost and high concentration. As reported in many studies, aeration of the fermentation medium aiming to optimize the percentage of dissolved oxygen in the medium has a stimulating effect on nisin production (Amiali et al. 1998; Cabo et al. 2001; Kordikanlioglu et al. 2015). In a study examining the effectiveness of the foam fractionation method to improve nisin production in the fermentation medium, the fermentation medium was subjected to foam fractionation with sterile air inlet at flow rate of $30 \mathrm{ml} \mathrm{min}^{-1}$ while the producer cell was in exponential growth phase. In this relevant study, maximum total nisin activity was measured as $4657 \mathrm{IU} \mathrm{ml}^{-1}$. This strategy resulted in a $36.2 \%$ increase in the total nisin activity measured in the control group fermentation performed with the conventional batch system ( Zheng et al. 2015). The aerotolerance of microorganisms is related to superoxide dismutase enzyme activity and the ability to induce NADH. Since L. lactis species are catalase negative, fermentation media is generally anaerobic. In fact, the aeration of the fermentation medium has an effect on promoting the growth and nisin production of L. lactis cells (Jiang et al. 2015; Kordikanliglu et al. 2015). In a study, which the relation between the aeration of the fermentation media and nisin production was determined, $10700 \mathrm{IU} \mathrm{ml}^{-1}$ nisin amount was produced in the anaerobic condition, where the production amount was $15400 \mathrm{IU} \mathrm{ml}^{-1}$ in the aerobic condition (Jiang et al. 2015).

There are also different ways of reducing the accumulation of lactate that adversely affect nisin production in L.lactis. Extraction of lactate in the medium using solvent or neutralization by 
alkalisation can be given as examples. Another innovative approach, unlike all these, is the mixed culture fermentation technique. The microorganism to be selected as an adjuvant to $L$. lactis in the mixed culture fermentation technique should meet certain criteria such as i) it should not have the ability to use the main carbon source, ii) must have the ability to use lactate, an inhibitor metabolite produced by L. lactis, iii) do not adversely affect the nisin produced by L. lactis, iv) increase the production of the desired target product, stimulate it. Yarrowia lipolytica that consumes lactate as a substrate source and the lactate producer L. lactis were simultaneously cultured in a fermentation medium that contains molasses and $50 \%$ increase was achieved in this mixed culture fermentation in nisin production compared to the control group where only L. lactis was used. While the nisin concentration in the control group was $170 \mathrm{mg} \mathrm{l}^{-1}$, it was $270 \mathrm{mg}^{-1}$ in the mixed culture (Ariana and Hamedi, 2017).

\section{Conclusion}

Nisin is the most widely known and applied lantibiotic and is the first and only bacteriocin allowed for use in food. Widespread use of nisin in biomedical applications, its therapeutic characteristic and as well as its production at industrial scale are the justifications for many studies to focus on to enhace its production and thereby reduce the cost. To date, many recombinant strains have been developed with different metabolic regulation to increase yields in producer strains. In non-molecular innovative approaches, the alternative ways have been developed to improve the adaptation capabilities of native strains to the conditions of the medium and such studies have been accelerated. It is inevitable that future research on nisin might be the fermentations used together with such innovative systems. When the innovative systems addressed above are upscaled to industrial scales, the factors that have limited nisin use will be tolerated to a great extent. 
353

Amiali, M.N., Lacroix, C., Simard, R.E. (1998). High nisin Z production by Lactococcus lactis UL719 in whey permeate with aeration. World J Microb Biotechnol., 14:887-894.

Arianaa, M. ve Hamedi, J. (2017). Enhanced production of nisin by co-culture of Lactococcus lactis sub sp. lactis and Yarrowia lipolytica in molasses based medium. Journal of Biotechnology, 256:21-26.

Belfiore, C., Castellano, P. and Vignolo, G. (2007). Reduction of Escherichia coli population following treatment with bacteriocins from lactic acid bacteria and chelators. Food Microbiol. 24:223-229.

Bertrand, N., Fliss, I., Lacroix, C. (2001). High nisin-Z production during repeated-cycle batch cultures in supplemented whey permeate using immobilized Lactococcus lactis UL719, Int. Dairy Jour., 11 (12): 953-960.

Bolotin, A., Mauger, S., Malarme, K., Ehrlich, S.D., Sorokin, A. (1999). Low redundancy sequencing of the entire Lactococcus lactis IL1403 genome, Ant. Van Leeuwen., 76:27-76.

Brooijmans, R.J., Smit, B., Santos, F., Riel, J.V., Vos, W., Hugenholtz, J. (2009). Heme and menaquinone induced electron transport in lactic acid bacteria. Microbiol Cell Fact. 8:14751486.

Bryan-Jones, D.G., Whittenbury, R. (1969). Haematin-dependent oxidative phosphorylation in Streptococcus faecalis, J. Gen. Microbiol., 58:247-60. 
Cabo, M.L., Murado, M.A., Gonzalez, M.P., Vazquez, J.A., Pastoriza, L. (2001). An empirical model for describing the effects of nitrogen sources on nisin production. Lett Appl Microbiol. 33(6):425-9.

Cheigh, C.I., Choi, H.J., Park, H., Kim, S., Kook, M., Kim, T., Hwang, J., Pyun, Y. (2002). Influence of growth conditions on the production of a nisin-like bacteriocin by Lactococcus lactis subsp. lactis A164 isolated from kimchi, J. Biotechnol., 95:225-235.

de Vuyst, L., Vandamme, E.J. (1992). Influence of the carbon source on nisin production in Lactococcus lactis subsp. lactis batch fermentations, J. Gen. Microbiol., 138:571-578.

Engelke, G., Gutowski-Eckel, Z., Hammelman, M., Entian, K-D. (1992). Biosynthesis of the lantibiotic nisin genomic organization and membrane localization of the NisB protein. Appl Environ Microbiol, 58: 3730-3743.

Graeffe, T., Rintala, H., Paulin, L. ve Saris, P. (1991). A natural nisin variant. In nisin and novel lantibiotics, Sci. Publishers, 260-268, (1991).

Gross, E., Morell, J.L. (1971). The structure of nisin. J. Am. Chem. Soc. 93; 4634-4635.

Hao, P., Liang, D., Cao, L., Qiao, B., Wu, H., Caiyin, Q., Zhu, H., Qiao, J. (2017). Promoting acid resistance and nisin yield of Lactococcus lactis F44 by genetically increasing D-Asp amidation level inside cell Wall. Appl Microbiol Biotechnol, 101:6137-6153

Hurst, A. (1981). Nisin. Adv. Appl. Microbiol. 27:85-123.

Jiang, L., Liu, Y., Yan, G., Cui, Y., Cheng, Q., Zhang, Z., Meng, Q., Teng, L., Ren, X. (2015). Aeration and fermentation strategies on nisin production, Biotechnol Lett., 37:2039-2045. 
391 Kim, W.S., Hall, R.J., Dunn, N.W. (1998). Improving nisin production by increasing immunity/resistance genes in the producer organisim Lactococcus lactis, Appl. Microbiol., 393 50(4):429-433.

394

395

396

397 398

Kong W, Lu T. (2014). Cloning and optimization of a nisin biosynthesis pathway for bacteriocin harvest. Biotechnol. 18;3(7):439-45.

Kordikanlioglu, B., Simsek, O., Saris P.E. (2015). Nisin production of Lactococcus lactis N8 with hemin-stimulated cell respiration in fed-batch fermentation system. Biotechnol Prog. 31(3):678-85.

Kuipers, O.P., Beerthuyzen, M.M., de Ruyter, P.G.G.A., Luesink, E.J., de Vos, W.M. (1995). Autoregulation of nisin biosynthesis in Lactococcus lactis by signal transduction. $J$ Biol Chem, 270: 27299-27304.

Kwaadsteniet, M., Doeschate, K. ve Dicks, L.M.T. (2008). Characterization of the structural gene encoding nisin F, a new lantibiotic produced by a Lactococcus lactis subsp. lactis isolate from freshwater catfish (Clarias gariepinus), Appl. Environ. Microbiol., 74, 547-549.

Lechardeur, D., Cesselin, B., Fernandez, A., Lamberet, G., Garrigues, C., Pedersen, M., Lv, W., Cong, W., Cai, Z. (2004). Nisin production by Lactococcus lactis subsp. lactis under nutritional limitation in fed-batch culture, Biotechnol. Lett., 26:235-238.

Liu, J., Maa, Z., Zhua, H., Caiyina, Q., Lianga, D., Wua, H., Huangd, X., Qiaoa, J. (2017). Improving xylose utilization of defatted rice bran for nisin production by overexpression of a xylose transcriptional regulator in Lactococcus lactis, Bioresource Tech., 238:690-697.

Luck, E., Jager, M. (1995). Nisin Antimicrobial, Food Additives, 27, 208-213. 
Malvido, C., González, A., Guerra, P. (2016). Nisin production in realkalized fed-batch cultures in whey with feeding with lactose- or glucose-containing substrates. Appl Microbiol Biotechnol. 100(18):7899-908.

Mulders, J.W.M., Boerrigter, I.J., Rollema, H.S., Siezen, R.J. ve de Vos, W.M. (1991). Identification and characterization of the lantibiotic nisin Z, a natural nisin variant, Eur. J. Biochem., 201, 581-584.

Ni, Z., Zhang, X., Liu, F., Wang, M., Hao, R., Ling, P., Zhu, X. (2017). Effect of Cooverexpression of nisin key genes on nisin production improvement in Lactococcus lactis LS01, Probiotics \& Antimicro. Prot., Baskıda.

Papagianni, M., Avramidis, N. (2012). Engineering the central pathways in Lactococcus lactis: functional expression of the phosphofructokinase (pfk) and alternative oxidase(aox1) genes from Aspergillus niger in Lactococcus lactis facilitates improvedcarbon conversion rates under oxidizing conditions, Enzyme Microb. Technol.,51(3):125-130.

Patent, US2935503 A. (1960). United States Patent Office, Production of nisin, Patented May 3.

Pedersen, M., Gaudu, P., Lechardeur, D., Petit, M. ve Gruss, A. (2012). Aerobic respiration metabolism in lactic acid bacteria and uses in biotechnology, Annu. Rev. Food Science Technology, 3, 37-58.

Pongtharangkul, T. ve Demirci, A. (2006). Evaluation of culture medium for nisin production in a repeated-batch biofilm reactor, Biotechnol. Prog., 22, 217-224. 
Ra, R., Qiao, M., Immonen, T., Pujana, I., Saris, P.E.J. (1996). Genes responsible for nisin synthesis, regulation and immunity form a regulon of two operons and a re induced by nisin in Lactococcus lactis N8. Microbiol, 142: 1281-1288.

Rezaiki, L., Cesselin, B., Yamamato, Y., Vido, K., van West, E., Gaudu, P. ve Gruss, A. (2004). Respiration metabolism reduces oxidative and acid stress to improve long-term survival of Lactococcus lactis, Mol. Biology, 53 (5): 1331-1342.

Sijpestejn, A.K. (1970). Induction of cytochrome formation and stimulation of oxidative dissimilation by hemin in Streptococcus lactis and Leuconostoc mesenteroides, Ant. van Leeuwen., 36:335-48.

Simsek, O., Akkoc, N., Con, A.H., Ozcelik, F., Saris, P.E.J. ve Akcelik, M. (2009). Continuous nisin production with bioengineered Lactococcus lactis strains, J. of Ind. Microbiol. Biotechnol., 36 (6):863-871.

Simsek, O., Con, A.H., Akkoc, N., Saris, P.E.J. ve Akcelik, M. (2009). Influence of growth conditions on the nisin production of bioengineered Lactococcus lactis strains, J. of Ind. Microbiol. Biotechnol., 36:481-490.

Simsek, O. (2014). Nisin production in a chitin-including continuous fermentation system with Lactococcus lactis displaying a cell wall chitin-binding domain, J. Ind. Microbiol. Biotechnol., 41:535-543.

Tramer, J. and Fowler, G. G. (1964). Estimation of nisin in foods. J. Sci. Food Agric. 15:522528. 
452

453

454

455

456

457

458

459

460

461

462

463

464

465

466

467

468

469

470

Wardani, A.K., Egawa, S., Nagahisa, K., Shimizu, H., Shioya, S. (2006). Robustness of cascade $\mathrm{pH}$ and dissolved oxygen control in symbiotic nisin production process system of Lactococcus lactis and Kluyveromyces marxianus. J Biosci Bioeng. 101(3):274-6.

Whittenbury, R. (1978). Biochemical characteristics of Streptococcus species, Soc. Appl. Bacteriol. Symp. Ser., 7:51-69.

Wirawan, R.E., Klesse, N.A., Jack, R.W. ve Tagg, J.R. (2006). Molecular and genetic characterisation of a novel nisin variant produced by Streptococcus uberis, Appl. Environ. Microbiol., 72, 1148-1156.

Zendo, T., Fukao, M., Ueda, K., Higuchi, T., Nakayama, J. ve Sonomoto, K. (2003). Identification of the lantibiotic nisin Q, a new natural nisin variant produced by Lactococcus lactis 61-14 isolated from a river in Japan, Biosci. Biotechnol. Biochem., 67, 1616-1619,

Zhang, J., Caiyin, Q., Feng, W., Zhao, X., Qiao, B., Zhao, G., Qiao, J. (2016). Enhance nisin yield via improving acid-tolerant capability of Lactococcus lactis F44. Sci Rep, 16;6:27973.

Zhang, Y.F., Liu, S.Y., Du, Y.H.,, Feng, W.J., Liu, J.H., Qiao, J.J. (2014). Genome shuffling of Lactococcus lactis subspecies lactis YF11 for improving nisin Z production and comparative analysis, J Dairy Sci. 97(5):2528-41.

Zheng, H., Zhang, D., Guo, K., Dong, K., Xu, D., Wu, Z. (2015). Online recovery of nisin during fermentation coupling with foam fractionation, Journal of Food Engineering, 162 :2530. 
471 Zhu, D., Zhao, K., Xu, H., Bai, Y., Zhang, X., Qiao, M. (2015). Effect of 6472 phosphofructokinase gene-pfk overexpression on nisin production in Lactococcus lactis N8.

473 Wei Sheng Wu Xue Bao. 4;55(4):440-7.

474

475

476

477

478

479

480

481

482

483

484

485

486

487 
Table 1. Recent innovative approaches resulting high nisin production.

\begin{tabular}{|c|c|c|c|}
\hline $\begin{array}{l}\text { Nisin } \\
\text { Producers }\end{array}$ & $\begin{array}{l}\text { Nisin } \\
\text { production }\end{array}$ & Innovative Approaches & Reference \\
\hline $\begin{array}{l}\text { L. lactis } \\
\text { ATCC11454 }\end{array}$ & $7900 \mathrm{IU} \mathrm{ml}^{-1}$ & $\begin{array}{l}\text { aoxl gene was cloned and the } \\
\text { rekombinant nisin producer was } \\
\text { induced to oxidative respiration. }\end{array}$ & $\begin{array}{l}\text { Papagianni et al. } \\
2012\end{array}$ \\
\hline $\begin{array}{l}\text { L. lactis } \\
\text { ATCC11454 }\end{array}$ & $14000 \mathrm{IU} \mathrm{m}^{-1}$ & $\begin{array}{l}\text { aox } 1 \text { gene was cloned together with } \\
p f k 13 \text { and } p k a \mathrm{C} \text { genes to increase the } \\
\text { glikolitic activity as well as the } \\
\text { oxidative respiration }\end{array}$ & $\begin{array}{l}\text { Papagianni et al. } \\
2012\end{array}$ \\
\hline $\begin{array}{l}\text { L. lactis } \\
\text { PLAC7 }\end{array}$ & $10500 \mathrm{IU} \mathrm{ml}^{-1}$ & $\begin{array}{l}\text { Chitin Binding Domain was cloned } \\
\text { in producer L. lactis and this was } \\
\text { used in continuous fermentation } \\
\text { system in presence of chitin }\end{array}$ & Şimşek, 2014 \\
\hline $\begin{array}{l}\text { L. lactis } \\
\text { YF11 }\end{array}$ & $4023 \mathrm{IU} \mathrm{ml}^{-1}$ & $\begin{array}{l}\text { Genome shuffling was applied to } \\
\text { improve nisin Z production of } L \text {. } \\
\text { lactis ssp. lactis YF11 via recursive } \\
\text { protoplast fusion. }\end{array}$ & Zhang et al. 2014 \\
\hline $\begin{array}{l}\text { L. lactis } \\
\text { N8 }\end{array}$ & $5410 \mathrm{IU} \mathrm{ml}^{-1}$ & $\begin{array}{l}\text { Fed-batch fermentation carried out } \\
\text { with hemin under aerobic conditions. }\end{array}$ & $\begin{array}{l}\text { Kordikanlioglu et } \\
\text { al. } 2015\end{array}$ \\
\hline $\begin{array}{l}\text { L. lactis } \\
\text { ATCC11454 }\end{array}$ & $4657 \mathrm{IU} \mathrm{ml}^{-1}$ & $\begin{array}{l}\text { Nisin was online recovered with } \\
\text { foaming fractionation from the } \\
\text { fermentation. }\end{array}$ & Zheng et al. 2015 \\
\hline $\begin{array}{l}\text { L. lactis } \\
\text { LD2 }\end{array}$ & $15400 \mathrm{IU} \mathrm{ml}^{-1}$ & $\begin{array}{l}\text { Nisin was produced in a aerated fed- } \\
\text { batch fermentation system with a } \\
\text { variable feeding rate. }\end{array}$ & Jiang et al. 2015 \\
\hline $\begin{array}{l}\text { L.lactis } \\
\text { F44 }\end{array}$ & $5560 \mathrm{IU} \mathrm{ml}^{-1}$ & $\begin{array}{l}\text { hdeAB, Idh and murF genes were } \\
\text { cloned and expressed simultaneously } \\
\text { to enhance the acidic tolerance of the } \\
\text { producer L. lactis. }\end{array}$ & Zhang et al. 2016 \\
\hline $\begin{array}{l}\text { L. lactis } \\
\text { F44A }\end{array}$ & $5346 \mathrm{IU} \mathrm{ml}^{-1}$ & $\begin{array}{l}\text { Acidic tolerance was enhanced by } \\
\text { overexpression the asnH gene at } \\
\text { nisin producer } L . \text { lactis }\end{array}$ & Hao et al. 2017 \\
\hline $\begin{array}{l}\text { L. lactis } \\
\text { UTMC106 }\end{array}$ & $10800 \mathrm{IU} \mathrm{ml}^{-1}$ & $\begin{array}{l}\text { This producer was used together with } \\
\text { Yarrowia lipolytica ATCC18942 in } \\
\text { fermentation system }\end{array}$ & $\begin{array}{l}\text { Ariana and } \\
\text { Hamedi, } 2017\end{array}$ \\
\hline
\end{tabular}




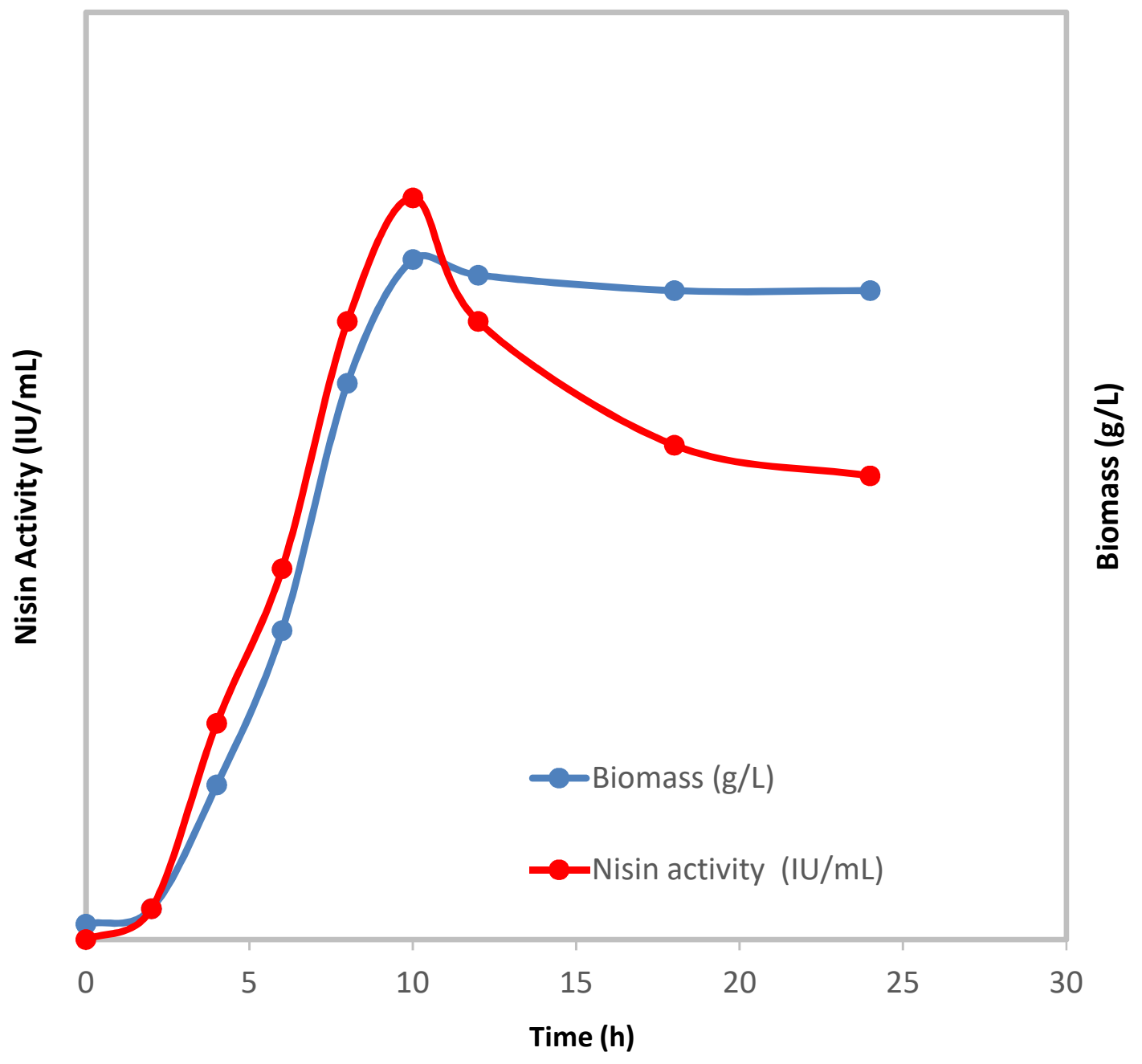

491

$492 \quad$ Figure1. Representative nisin production and biomass amount of nisin producer L. lactis in 493 batch fermentation systems.

494

495

496

497

498 


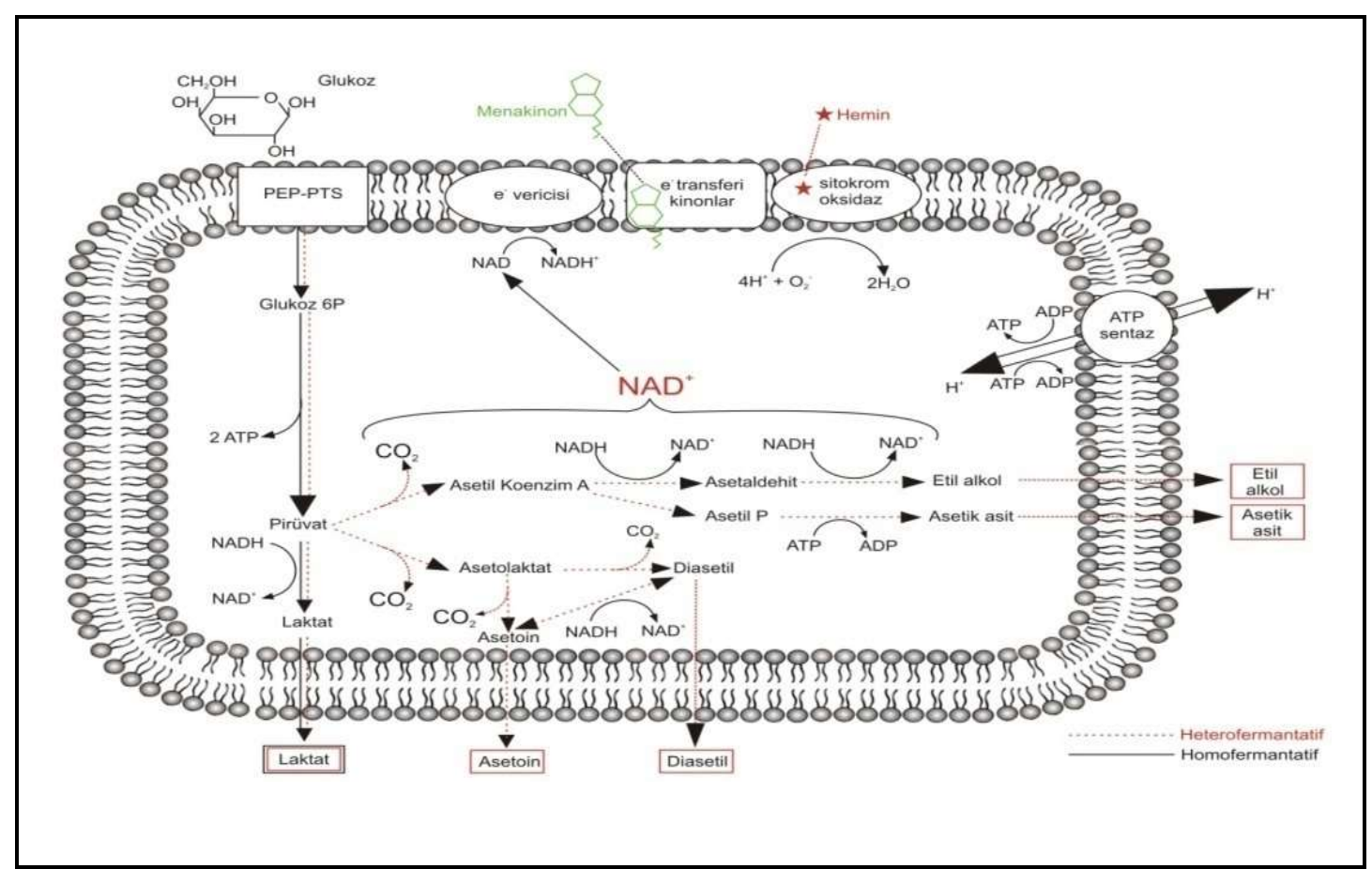

501

502 Figure 2. The metabolic pathway followed by the L.lactis bacteria induced for oxidative 503 respiration. 